logos_i_ethos_2019_2_(50), s. 27-46

DOI: http://dx.doi.org/10.15633/lie.3476

Tadeusz Biesaga SDB

https://orcid.org/0000-0003-0863-4422

Uniwersytet Papieski Jana Pawła II w Krakowie

\title{
Eugenika w propozycjach legalizacji prawa do zdrowej reprodukcji
}

\section{Nieosądzone zbrodnie eugeniki}

Przy końcu XIX i na początku $\mathrm{XX}$ wieku powstały różne ideologie inżynierii społecznej, które miały rozwiązać problem biedy i dobrobytu społeczeństw. Były to: 1) Thomasa Malthusa propozycja ograniczenia wzrostu demograficznego ludności, czyli ograniczenia rozmnażania się biednych; 2) Francisa Galtona program selekcji eugenicznej, czyli oczyszczenia społeczeństwa z obciążonych biologicznie dziedzicznymi schorzeniami; 3) Margaret Sanger eugeniczno-aborcyjny program kontroli urodzeń przez antykoncepcję, sterylizację i aborcję; 4) Karola Marksa program przezwyciężenia wyzysku i biedy przez walkę klas oraz 5) Adolfa Hitlera program narodowego socjalizmu, panowania silnej rasy niemieckiej.

Owe ideologie wzajemnie na siebie oddziaływały i wzajemnie się wspierały. Tak np. lęk demograficzny, czyli lęk przed wzrostem liczby ludności i katastrofą biologiczną ras i narodów, był wykorzystywany przez feministyczny ruch kontroli urodzeń metodami sterylizacji, antykoncepcji i aborcji. Projekt gazowania wyselekcjonowanych chorych, propagowany w gronie eugeników amerykańskich, został później 
zrealizowany przez niemiecką medycynę nazistowską. Mimo że projekt ten nie został zalegalizowany w USA, to jednak niemieccy naukowcy przejęli idee eugeniczne od naukowców amerykańskich ${ }^{1}$. Hitler już w więzieniu zapoznał się z przetłumaczonymi dziełami eugeników amerykańskich i nawet osobiście dziękował niektórym z nich za doskonałe jego zdaniem propozycje, które później zastosował w postaci legalizacji aborcji eugenicznej oraz masowego zabijania w komorach gazowych chorych dzieci i dorosłych. Dziękował on np. Madisonowi Grantowi (1865-1937), prezesowi Towarzystwa Zoologicznego w Nowym Jorku, za jego książki, które traktował jako „biblię nowoczesnej eugeniki”. Ów eugenik i rasista w propagowaniu ideologii eugenicznej odrzucał prawo do życia, pisząc: „nieuzasadniony szacunek dla praw boskich i sentymentalna wiara w świętość życia stoją na przeszkodzie zarówno eliminacji upośledzonych noworodków, jak i sterylizacji dorosłych, nieprzedstawiających żadnej wartości dla społeczeństwa. Prawa natury domagają się unicestwienia nieprzystosowanych, a ludzkie życie wtedy tylko ma wartość, kiedy służy społeczności lub rasie"2.

Eugenicy zarówno głosili idee ochrony narodu przed zdegenerowanymi obywatelami, jak i sugerowali konieczność instytucjonalnej realizacji tej idei. „Proces nacjonalizacji eugeniki, tj. jej transformacji w rodzaj «nauki narodowej», zajmującej się zagadnieniami ochrony zdrowia określonego narodu, wzmógł się już w latach I wojny światowej, ale dopiero wskutek politycznych i terytorialnych zmian wprowadzonych po zawarciu traktatów pokojowych eugenicy zmodyfikowali strategię działania, zwracając większą uwagę na agitację i propagandę defensywnego nacjonalizmu"3.

1 Por. E. Black, Wojna przeciw słabym - eugenika i amerykańska kampania na rzecz stworzenia rasy panów, Warszawa 2004.

2 M. Grant, The Passing of the Great Race or Racial Basis of European History, New York 1916, s. 49.

${ }^{3}$ M. Turda, Eugenika negatywna w Europie przed 1933 r., w: Eugenika - biopolityka - państwo: $z$ historii europejskich ruchów eugenicznych w pierwszej połowie XX w., red. M. Gawin, K. Uzarczyk, Warszawa 2010, s. 33. 
Etos nauki umożliwiał eugenikom podjęcie się roli obrońców i protektorów narodu ${ }^{4}$. Posługując się autorytetem nauki, głosili oni konieczność obrony przed degeneracją biologiczną społeczeństwa. Wzbudzali lęk, twierdząc, że bez przeprowadzenia oczyszczenia z jednostek zdegenerowanych rasy i narody zmierzają ku katastrofie. Uzasadniali konieczność przeprowadzenia takiej operacji na wielką skalę przez instytucje państwowe. Autorytetem nauki wspierali przeprowadzenie przez państwo i jego instytucje eugenicznej selekcji i inżynierii społecznej. Zmierzali do radykalnych rozwiązań, w tym również nacjonalistycznych czy rasistowskich, propagując ostateczne rozstrzygnięcia kwestii kondycji biologicznej przyszłych pokoleń. Uogólniając, można powiedzieć, że to właśnie wybitni naukowcy - eugenicy XX wieku przygotowali grunt pod medycynę nazistowską, która ich idee brutalnie zrealizowała ${ }^{\text {. }}$.

Po drugiej wojnie światowej, w procesie norymberskim zostały potępione i osądzone zbrodnie medycyny nazistowskiej, ale niestety nie zostały osądzone jako takie zbrodnie ideologii eugenicznej, która jeszcze przed nazizmem podzieliła ludzkość na część wartą i niewartą życia oraz propagowała różne drogi eliminacji tej drugiej części ${ }^{6}$. Zbrodnie niektórych medyków nazistowskich były uznane jako zbrodnie wojenne, zbrodnie systemu politycznego, wynikające z ich przynależności do SS czy do innych struktur państwa nazistowskiego. Zbrodnie eugeników nie były wprost nazwane i osądzone. Sąd norymberski nie potępił zbrodni inspirowanych eugeniką nie tylko uczonych niemieckich, ale i uczonych tzw. świata cywilizowanego. Nie dostrzegł związku między poglądami i działaniami eugeników, uznających część ludzkości za niewartą życia, a działaniami medyków nazistowskich, którzy te idee realizowali w postaci eugenicznej aborcji, okrutnych eksperymentów na więźniach

4 Por. M. Turda, Eugenika negatywna w Europie przed 1933 r., dz. cyt., s. 31.

5 Por. C. Żekanowski, Genetyka medyczna: problemy i zagrożenia, w: Granice ingerencji w nature, red. B. Chyrowicz, Lublin 2001, s. 89-90.

${ }^{6}$ Por. K. Binding, A. Hoche, Die Freigabe der Vernichtung Lebensunwerten Lebens, Leipzig 1920. 
obozów koncentracyjnych oraz poprzez zabijanie gazem chorych dzieci i dorosłych ${ }^{7}$.

„Proces uświadamiania związku między nazistowskim ludobójstwem a teorią eugeniczną - pisze Magdalena Gawin - nie dokonał się w umysłach ludzi od razu"s. Było to niewygodne zarówno dla naukowców niemieckich, jak i amerykańskich czy angielskich, którzy w swych publikacjach naukowych formułowali tezy o konieczności eugenicznego oczyszczenia ras i ludzkości. Skupiono się na ludobójstwie dokonanym przez Hitlera, a pominięto osąd prowadzących do tego poglądów szerokiego gremium najwybitniejszych naukowców rozwiniętego świata, których teorie zostały w Niemczech wprowadzone w czyn. Poza tym, w wyniku powstałych nowych bloków politycznych, naukowcy - w tym również nazistowscy - byli potrzebni do rozwoju badań przydatnych do prowadzenia zimnej wojny. Zakłamywano rzeczywistość, twierdząc, że medycyna nazistowska czy eugenika były pseudonaukami, za które nie mogą odpowiadać autorytety naukowe. Nawet dziś porównanie zbrodni eugenicznych do zbrodni niemieckiej medycyny nazistowskiej spotyka się z ostrym sprzeciwem.

Brak osądzenia i potępienia $\mathrm{w}$ procesie norymberskim zbrodni eugenicznych, które były inspirowane przez naukowców i wspierane finansowo przez bogatą elitę chcącą mieć zdrowych i sprawnych robotników w swoich fabrykach, jest jedną z przyczyn kontynuacji tego procederu współcześnie. „Pod wpływem doświadczenia II wojny światowej, skali narodowosocjalistycznych zbrodni i zaangażowania w nie wielu niemieckich naukowców i lekarzy, eugenikę potępiano jako należącą do przeszłości, a w Niemczech unieważniano odpowiednie regulacje prawne. Rzeczywistość była bardziej skomplikowana. Rozpoczął się szybki proces odchodzenia od eugeniki negatywnej i kryteriów rasowych. Kontynuowano natomiast $\mathrm{w}$ wielu krajach eugenikę w nietotalitarnej

7 Por. P. Madajczyk, Rozliczenie z eugenika i higiena rasowa po zakończeniu II wojny światowej, w: Medycyna w cieniu nazizmu, red. M. Musielak, K. B. Głodowska, Poznań 2015, s. 104.

${ }^{8}$ M. Gawin, Eugenika peryferii w pierwszej połowie XX w. w kontekście polskim, w: Eugenika biopolityka - państwo: $z$ historii europejskich ruchów eugenicznych w pierwszej połowie XX w., dz. cyt., s. 11 . 
i nierasistowskiej wersji, także wykorzystującej przymus. Przykładowo, kraje skandynawskie przerwały eugeniczne programy na począt$\mathrm{ku}$ lat 70. [...] Po 1945 r. eugeniczne poglądy w nierasistowskiej formie były akceptowane przez dużą część międzynarodowych środowisk naukowych i lekarskich oraz opinii publicznej"'.

Ponieważ nie dało się ukryć przed opinią publiczną oczywistego związku eugeniki z medycyną nazistowską i z eksterminacją oraz ludobójstwem chorych, eugenicy, nie zmieniając swoich poglądów, szybko przemianowali się na genetyków. Czasopisma eugeniczne zmieniły tytuły na czasopisma genetyczne. Eugenika mogła użyć teraz nowych, lepszych narzędzi dzielenia ludzi na wartych i niewartych życia. „Od lat 50. XX w. stwierdza Paul Weindling - widoczne jest odchodzenie od eugeniki na rzecz «genetyki człowieka» [...]. Nowe odkrycia w dziedzinie biologii molekularnej i zrozumienie uwarunkowań genetycznych oznaczały świt ery, w której dawniejsze marzenia o inżynierii genetycznej i dzieciach z probówki mogły zostać zrealizowane. [...] Pojawiła się nowa, powojenna polityka populacyjna, $\mathrm{z}$ aktywnym udziałem grup feministycznych, podkreślających prawo do wyboru kobiety w kwestiach związanych z prokreacją, edukacją i prawem do pracy. Nie zakończyła się ostra rywalizacja nauki i polityki w odniesieniu do zagadnienia prokreacji. Od lat 50. wiedza w zakresie genetyki i technologii reprodukcji poczyniła ogromne postępy, pozostaje jednak przedmiotem kontrowersji kwestia, na ile był to świt nowej ery w nauce, dającej jednostce większe możliwości, a na ile było to po prostu opatrzenie nową etykietką dawnego programu eugenicznego"10.

Dzięki nowym możliwościom medycznym i radykalizującym się ideologiom feministycznym program eugeniczny $\mathrm{z}$ nowym impetem wkroczył w czasy współczesne.

9 P. Madajczyk, Rozliczenie z eugeniką i higiena rasową po zakończeniu II wojny światowej, dz. cyt., s. 110 .

10 P. Weindling, Krytycy, komentatorzy i przeciwnicy eugeniki 1880-1950, w: Eugenika - biopolityka-państwo: $z$ historii europejskich ruchów eugenicznych w pierwszej połowie XX w, dz. cyt., s. 62 . 


\section{Ruchy feministyczne i konferencje ONZ o prawach reprodukcyjnych}

Ideologie antynatalistyczne przed drugą wojną światową i po niej propagowane były przez maltuzjańskie podejście do demografii, eugeniczne traktowanie prokreacji oraz feministyczne programy kontroli urodzeń, powiązane z hasłami wyzwolenia kobiet. „Koncepcja praw reprodukcyjnych i seksualnych nierozerwalnie związana jest $\mathrm{z}$ ruchem feministycznym, szczególnie działalnością feministek tzw. II fali" ${ }^{11}$. W latach 60. XX wieku ruch feministyczny zradykalizował swoje dążenia do wyzwolenia kobiet, upatrując przyczyny zniewolenia w relacji między płcią biologiczną a płcią społeczno-kulturową. Wyzwoleniem z dotychczasowych struktur płci społeczno-kulturowej miał być permisywizm seksualny, propagowanie lesbijskich związków między kobietami wraz z wrogością i odrzuceniem funkcji prokreacyjnej kobiety, traktowanej jako główna przyczyna nierówności między kobietami i mężczyznami. To wtedy feministki zaadaptowały do sfery płciowości marksistowskie dążenia do zniesienia klas społecznych. Uznały one, że to nie tyle klasy ekonomiczne są powodem zniewolenia, ile klasy płciowe, czyli podział na mężczyzn i kobiety. Tak jak w marksizmie wyeliminowanie klas ekonomicznych miało się dokonać w wyniku przejęcia przez proletariat środków produkcji, tak w neomarksizmie wyeliminowanie klas płciowych urzeczywistni się dzięki przejęciu przez kobiety kontroli nad środkami reprodukcji, czyli prokreacji. Proces ten ma być przeprowadzony drogą rewolucyjnej przebudowy kultury poprzez narzucenie całkowicie odmiennej płci kulturowej. Dla owej rewolucji zanegowano związek płci biologicznej z kulturową i zaproponowano przyjęcie tylko płci kulturowej. Uznano, że dotychczasowe rozumienie kobiecości, męskości, macierzyństwa i ojcostwa należy odrzucić jako wymyślone przez patriarchalne struktury zniewolenia kobiet i zastąpić płciowością oswobodzoną od prokreacji. Postulowano „likwidację instytucji macierzyństwa biologicznego, uczynienie

11 K. Dobrowolska, Prawa reprodukcyjne i seksualne w ONZ $i$ ich doktrynalne uwarunkowania, „Zeszyty Prawnicze” 16 (2016) nr 2, s. 165. 
sztucznej reprodukcji powszechnym sposobem rozmnażania" ${ }^{12}$. Zalecano zniesienie instytucji małżeństwa i przejęcie wychowania dzieci przez grupy kobiet czy mężczyzn lub jakieś wspólnoty niezwiązane biologicznie $\mathrm{z}$ tymi dziećmi. W ten sposób kobiety byłyby wyzwolone z biologicznego macierzyństwa, ze znoju rodzenia i wychowania dzieci, bo dzieci sztucznie poczęte byłyby wychowywane przez pewne grupy dorosłych podejmujące się tej pracy. „Radykalny nurt feminizmu bardzo konsekwentnie odżegnuje się zatem od łączenia seksualności z prokreacją i z macierzyństwem $\mathrm{w}$ tradycyjnym rozumieniu, widząc $\mathrm{w}$ rodzinie opartej na biologicznych więzach instrument opresji i wyzysku kobiet"13.

Swoje postulaty ruch ten realizuje właśnie poprzez ideę praw reprodukcyjnych oraz lobbowanie na rzecz wymyślonych uprawnień w organizacjach międzynarodowych ONZ i UE. Próby zmiany mentalności w kwestii prokreacji, małżeństwa i rodziny, rozumienia kobiecości i męskości, ojcostwa i macierzyństwa podejmowane są odgórnie poprzez międzynarodowe konferencje, w których uczestniczą nie tylko zwolennicy radykalnego feminizmu, lecz także zwolennicy eugeniki, depopulacji, propagatorzy genderyzmu, antykoncepcji i aborcji. Zasadniczą ideą przenikającą te wszystkie tendencje jest idea dopatrywania się w prokreacji, w macierzyństwie i w rodzinie powodów dyskryminacji kobiet. Pod przykrywką działań przeciwdyskryminacyjnych dąży się do uwolnienia kobiet od płodności, czyli oderwania seksualności od macierzyństwa, i legalizacji - odpowiednio do tej idei - praw reprodukcyjnych.

Największy wysiłek w proponowaniu praw reprodukcyjnych i seksualnych podjęto na Międzynarodowej Konferencji ds. Ludności i Rozwoju zorganizowanej w Kairze w roku 1994. Po raz pierwszy użyto tam oficjalnie terminu „zdrowie reprodukcyjne i seksualne” oraz terminu "prawa reprodukcyjne" ${ }^{\text {"14 }}$. W proponowanym na konferencji dokumencie

12 K. Dobrowolska, Prawa reprodukcyjne i seksualne w ONZ i ich doktrynalne uwarunkowania, dz. cyt., s. 167.

${ }^{13}$ K. Dobrowolska, Prawa reprodukcyjne i seksualne w ONZ i ich doktrynalne uwarunkowania, dz. cyt., s. 168.

14 Programme of Action of the United Nations International Conference on Population \& Development, http:// www.iisd.ca/Cairo/program/p00000.html (6.10.2019). 
chodziło o to, aby „prawa reprodukcyjne” potraktować jako prawa człowieka i zaliczyć do nich również prawo do aborcji na życzenie. Dokument miał naciskać na państwa, aby legalizowały powyższe uprawnienia oraz stworzyły sieć „usług aborcyjnych” umożliwiające realizację tych uprawnien ${ }^{15}$. Mimo że $\mathrm{w}$ wyniku sprzeciwu $\mathrm{w}$ dokumencie końcowym odrzucono propagowanie aborcji jako metody planowania rodziny, to jednak dalej ukryto to dążenie w konstrukcji prawa do zdrowia reprodukcyjnego ${ }^{16}$.

Kontynuacją ideologii praw reprodukcyjnych była IV Światowa Konferencja ONZ w sprawach Kobiet w Pekinie w 1995 roku. „To podczas tej konferencji po raz pierwszy użyto sformułowania «gender» zamiast «sex» na określenie płci, co miało ogromne znaczenie dla późniejszego kształtowania się międzynarodowych regulacji prawnych w zakresie polityki równościowej” ${ }^{17}$. To właśnie na tej konferencji domagano się, aby perspektywę kulturowej tożsamości płci (gender perspective) włączyć do ustawodawstwa państwowego, w celu realizacji polityki oraz różnych programów i projektów.

Na terenie Polski, za poprzedniego rządu w latach 2007-2015, Komitet Bioetyczny przy PAN, lansował legalizację praw reprodukcyjnych $\mathrm{w}$ dokumencie $\mathrm{nr} 1 \mathrm{z} 2012$ roku $^{18}$ oraz $\mathrm{w}$ dokumencie $\mathrm{nr} 4 \mathrm{z}$ roku $2013{ }^{19}$, poświęconym kwestii sumienia, w których oskarżał też lekarzy polskich o nadużywanie klauzuli sumienia i domagał się prawnego ograniczenia tej klauzuli w odniesieniu do polskich lekarzy nieprzestrzegających

15 Por. T. Biesaga, Źródła ideologii aborcyjnej, „Medycyna Praktyczna” 3 (2005), s. 30.

16 Por. G. Weigel, What Really Happened at Cairo, „First Things” 50 (1995), s. 24-31.

17 K. Dobrowolska, Prawa reprodukcyjne i seksualne w ONZ i ich doktrynalne uwarunkowania, dz. cyt., s. 175.

18 Komitet Bioetyczny przy Prezydium PAN, Stanowisko Komitetu Bioetycznego przy Prezydium PAN nr 1/2012 w sprawie etycznych problemów medycyny reprodukcyjnej i genetyki klinicznej oraz konieczności ich regulacji prawnej, s. 1-2, pkt 4, http://www.bioetyka.pan.pl/images/stories/Pliki/ stanowisko\%20kb\%20nr\%201-2012.pdf (6.10.2019).

19 Komitet Bioetyczny przy Prezydium PAN, Stanowisko Komitetu Bioetycznego przy Prezydium PAN $n r$ 4/2013 z 12 listopada 2013 roku w sprawie tzw. klauzuli sumienia, s. 1-12, http://www.bioetyka.pan.pl/images/stories/Pliki/Stanowisko\%20KB\%20nr\%204-2013.pdf (6.10.2019). 
rzekomych praw reprodukcyjnych ${ }^{20}$. W paragrafie 2 pierwszego dokumentu domagano się poszerzenia dotychczasowych uprawnień reprodukcyjnych. „Komitet Bioetyki jest zdania - czytamy w dokumencie - że przyjęta regulacja powinna dopuszczać niepartnerskie dawstwo gamet i zarodków, kriokonserwację gamet i zarodków oraz możliwość stosowania genetycznej diagnostyki preimplantacyjnej w celu określenia stanu zdrowia embrionów in vitro" ${ }^{21}$. Komitet posługuje się już eugenicznym terminem „zdrowia reprodukcyjnego" jako uprawnieniem nie tylko do pozapartnerskiego dawstwa gamet do zapłodnień in vitro, ale również jako uprawnieniem do poradnictwa o różnych metodach zapobiegania ciąży, do przerywania ciąży, czyli eugenicznej selekcji aborcyjnej. To właśnie owymi prawami reprodukcyjnymi Komitet podważa wolność i klauzulę sumienia, ograniczając ją w przypadku lekarzy i odmawiając jej innym przedstawicielom służby zdrowia.

\section{Eliminacja eugeniczna jako obowiązek moralny}

Libertyńscy i utylitarystyczni eugenicy, tacy jak Julian Savulescu czy John Harris, w swoich teoretycznych propozycjach idą jeszcze dalej niż antynatalistyczne nurty feministyczne i demograficzne i traktują eugeniczną eliminację człowieka w okresie prenatalnym jako obowiązek moralny ${ }^{22}$. W tym celu posługują się oni pojęciem "doskonałego dziecka” (perfect baby). Nie ograniczają się do proponowania zabijania chorych czy niepełnosprawnych dzieci w okresie prenatalnym, lecz zalecają, aby przed urodzeniem eliminować również zdrowe dzieci, jeśli nie spełniają one kryteriów zaprojektowanego najlepszego dziecka.

W 2001 roku wpływowy bioetyk angielski Julian Savulescu w artykule Procreative Beneficence: Why We Should Select the Best Children

20 Por. T. Biesaga SDB, Spór o klauzule sumienia lekarzy w Polsce, w: Primum philosophari. Opuscula Antonio Siemianowski dedicata, red. J. Grzeszczak, K. Stachewicz, Poznań 2016, s. 283-299.

${ }^{21}$ Komitet Bioetyczny przy Prezydium PAN, Stanowisko Komitetu Bioetycznego przy Prezydium PAN nr 4/2013 z 12 listopada 2013 roku w sprawie tzw. klauzuli sumienia, dz. cyt., s. 1-12.

${ }^{22}$ Por. M. Soniewicka, Selekcja genetyczna w prokreacji medycznie wspomaganej. Etyczne i prawne kryteria, Warszawa 2018, s. 281-287. 
zachęcił przyszłych rodziców do preimplantacyjnej albo prenatalnej selekcji dzieci ze względu na zaplanowane wcześniej ich cechy biologiczne $^{23}$. Selekcję taką umożliwiają preimplantacyjna, genetyczna diagnostyka (PGD) i techniki zapłodnienia in vitro (IVF). Jego zdaniem nic nie stoi na przeszkodzie, aby takiej selekcji dokonywać nie tylko w przypadku defektów genetycznych, ale w celu urzeczywistnienia pożądanych przez rodziców cech dziecka. Nie chodzi w tym wypadku o wykorzystanie informacji genetycznych do eliminacji dzieci ze względu na przewidywane przyszłe choroby, ale o wykorzystanie wiedzy genetycznej do selekcji preimplantacyjnej albo prenatalnej dzieci w celu wyselekcjonowania wybranych przez rodziców takich cech dziecka, które będą im służyć do lepszego, szczęśliwego życia. Autor tej propozycji skupił się na propagowaniu selekcji genetycznej ze względu na wybór przez rodziców określonej płci dziecka i wybór stopnia jego inteligencji (on genes for intelligence and sex selecion) ${ }^{24}$. Jego zdaniem, jeśli mamy in vitro np. cztery embriony ludzkie, to genetyczne testy predyspozycji do wysokiego IQ powinny wskazać, które embriony odrzucić, a który z nich implantować. Postępujące badania dotyczące możliwych związków pewnych informacji genetycznych z predyspozycjami do inteligencji winny być wykorzystane do podejmowania reprodukcyjnych decyzji. Autor ilustruje to grą, w której jeśli w pudle A zgromadziło się milion dolarów, a w pudle $\mathrm{B}$ tylko sto dolarów, to racjonalnie jest wybrać to, co zgromadzono w pudle $\mathrm{A}^{25}$.

W oparciu o taki prosty przykład oraz sugestię, że przecież chodzi nam o dobro i szczęście naszego dziecka, autor staje na stanowisku, że selekcja reprodukcyjna jest dobrodziejstwem i obowiązkiem moralnym. „Małżonkowie (lub indywidualni reproduktorzy), na podstawie odpowiednich, osiągalnych informacji - stwierdza ów bioetyk - powinni

${ }^{23}$ J. Savulescu, Procreative Beneficence: Why We Should Select the Best Children, „Bioethics” 15 (2001) no. 5/6, s. 414-426.

24 Zob. J. Savulescu, Procreative Beneficence: Why We Should Select the Best Children, dz. cyt., s. 413 .

25 Zob. J. Savulescu, Procreative Beneficence: Why We Should Select the Best Children, dz. cyt., s. 414 
przeprowadzić selekcję tych dzieci, które mogą posiadać, przewidując, że [wyselekcjonowane] będą mieć najlepsze życie (best life) lub przynajmniej takie dobre życie, jakie mają inni. [...] Osoba, która ma dobry powód, aby mieć najlepsze dziecko, jest moralnie zobowiązana mieć dziecko najlepsze (best child)" ${ }^{26}$. W artykule z 2009 roku Julian Savulescu i Guy Kahane przedstawiają zasadę prokreatywnego dobrodziejstwa (Principle of Procreative Beneficence) nie tylko jako możliwość wyboru, ale wręcz jako obowiązek moralny ${ }^{27}$.

W propozycji tej nie chodzi im tylko o eliminację aborcyjną dzieci z genami mogącymi wywołać choroby, lecz o eliminację preimplantacyjną i aborcyjną dzieci, u których wskazano geny mogące powodować lub tworzyć nieakceptowane lub zbyt słabe dyspozycje do pewnych stanów fizycznych czy psychicznych osoby, takich np. jak wzrost, inteligencja, charakter, pamięć i inne różne uzdolnienia (to select offspring on the basis of non-disease genes). Chodzi o uzdolnienia potrzebne dla najlepszego, szczęśliwego życia.

Genetyka behawioralna - zdaniem wymienionego bioetyka - dostarczy nam informacji o różnych genetycznych predyspozycjach, według których rodzice powinni dokonywać selekcji dzieci w okresie prenatalnym. Powinni oni zdobywać informacje o genach mogących sprzyjać dyspozycjom do agresji czy zachowań kryminalnych, alkoholizmu, ADHD, antyspołecznych zachowań, skłonności homoseksualnych, stanów neurotycznych czy schizofrenicznych oraz posiadać informacje o genach mogących sprzyjać lepszej kreatywności, pamięci i inteligen$\mathrm{cji}^{28}$. Według wymienionych bioetyków jesteśmy zdeterminowani genetycznie i dlatego należy eliminować geny, które mogą powodować przemoc, łamanie prawa, konflikty społeczne, niszczenie relacji społecznych i generowanie cierpienia. Społeczeństwo, przyszli rodzice mogą określić, na czym polega najlepsze życie (best life) i zgodnie z tymi kryteriami

26 J. Savulescu, Procreative Beneficence: Why We Should Select the Best Children, dz. cyt., s. 415.

27 Zob. J. Savulescu and G. Kahane, The Moral Obligation to Create Children with the Best Chance of the Best Life, „Bioethics” 23 (2009) no. 5, s. 274-290.

28 Zob. J. Savulescu, Procreative Beneficence: Why We Should Select the Best Children, dz. cyt., s. 417. 
przeprowadzać preimplantacyjną i aborcyjną selekcję genetyczną, aby wyselekcjonować najlepsze dziecko (best child) ${ }^{29}$.

Savulescu stara się odróżnić swoją propozycję prokreatywnego dobrodziejstwa (Procreative Beneficence) od przymusowej eugeniki, stosowanej przed drugą wojną światową i po niej. Uważa, że jego propozycja różni się od przymusowej sterylizacji, a w medycynie nazistowskiej od zabijania chorych gazem w obozach koncentracyjnych. Zasada prokreatywnego dobrodziejstwa i obowiązek selekcji prenatalnej jest bowiem dobrowolnym aktem przyszłych rodziców i ich moralnym obowiązkiem, aby tą drogą mieć najlepsze dzieci dla pożytku ich i społeczeństwa ${ }^{30}$. Rodzice ci inspirują się oczekiwaniem, że owe najlepsze dzieci osiągną najlepszy dobrostan (well-being), czyli osiągną pełnię szczęścia, niejako raj na ziemi. Tak więc w miejsce instytucji państwowych desygnuje on rodziców, klasę dorosłych, która ma decydować o życiu i śmierci klasy nieurodzonych.

\section{Wobec propagatorów współczesnej eugeniki}

Okazuje się, że w projekcie obowiązku moralnego wyselekcjonowania najlepszych dzieci powtarzają się przemilczenia i błędne założenia eugeniki przymusowej, zrealizowanej w medycynie nazistowskiej. Po pierwsze, przemilczany i ignorowany jest status ontyczny i moralny dziecka w okresie prenatalnym. Savulescu całkowicie pomija prawa człowieka w okresie prenatalnym, ignoruje toczące się dyskusje w tym względzie oraz argumenty pro-life, które są uzasadniane filozoficznie, teologicznie, moralnie i religijnie. $Z$ góry przyznaje klasistyczne uprawnienia dorosłym, jakoby oni mieli prawo decydować o selekcji poczętych, istniejących dzieci na rzecz „wyhodowania” dzieci lepszych genetycznie i biologicznie.

29 Zob. J. Savulescu, Procreative Beneficence: Why We Should Select the Best Children, dz. cyt., s. 420 .

30 Zob. J. Savulescu, Procreative Beneficence: Why We Should Select the Best Children, dz. cyt., s. 424 . 
Proponowana selekcja eugeniczna, zdaniem jej krytyków, zbudowana jest na tym samym założeniu, które występowało w przedwojennej eugenice amerykańskiej czy nazistowskiej, czyli na uznaniu ludzi niepelnosprawnych jako mniej wartościowych. Jest to propozycja poniżająca niepełnosprawnych, również tych obecnie żyjących w danej społeczności i pomyślnie i szczęśliwie realizujących swoje życie ${ }^{31}$. Z moralnego punktu widzenia błędne jest stwierdzenie, że postępowanie ludzi niepełnosprawnych w porównaniu z pełnosprawnymi jest moralnie mniej wartościowe. Wartościowanie moralne dotyczy bowiem realizacji człowieczeństwa człowieka, a nie realizacji materialnych korzyści społeczeństwa.

Savulescu - według krytyków jego propozycji - w swoim propagowaniu obowiązku selekcji prenatalnej dzieci odwołuje się do fikcyjnych obietnic. Okazuje się bowiem - stwierdza Alan Holand - że decyzji przyszłych rodziców o zmianie i ulepszeniu jakichś cech genetycznych ich dzieci nie da się powiązać $z$ ich przyszłym dobrym życiem ${ }^{32}$. Nie można powiązać decyzji dotyczących jakichś właściwości biologicznych z przyszłym życiem moralnym dziecka, z tym np., że dziecko będzie wiodło dobre życie $\mathrm{w}$ duchu chrześcijańskim, że będzie go widzieć w naśladowaniu Chrystusa. Stan biologiczny czy genetyczny człowieka nie determinuje życia moralnego. Człowiek staje się dobrym człowiekiem przez dobre wybory, dobre postępowanie. Każdy ma możliwość realizacji dobrego życia. Dobre moralnie życie nie jest uzależnione od biologicznej kondycji. To dzięki duchowemu otwarciu chrześcijaństwo pierwszych wieków szybko się rozprzestrzeniało. $\mathrm{W}$ proponowanych programach biologicznej manipulacji człowiekiem takie możliwości są zacieśnione.

Nie da się ustalić cech najlepszego życia (best life) - stwierdza Alan Holland - przez porównanie życia jednego człowieka $z$ drugim. Nie sposób obiektywnie porównać życia A, B, i C i stwierdzić, które z nich jest najlepsze, gdyż dokonujemy porównań z różnych względów. „Życie

31 Por. R. Bennett, The Fallacy of the Principle of Procreative Beneficence, „Bioethics” 23 (2009) no. 5 , s. 265-273, s. 266.

32 Zob. A. Holland, The Case Against the Case for Procreative Beneficence (PB), „Biethics” 30 (2016) no. 7, s. 491. 
A może być lepsze od B ze względu na x, życie B może być lepsze od C ze względu na y, a życie C może być lepsze od A ze względu na z. Nie ma możliwości wywnioskowania, które życie $\mathrm{z}$ wymienionych jest najlepsze"33.

Nie da się również ustalić tego, co najlepsze, przez stopniowanie i zwiększanie tego, co dobre. Jeśli ciepło jest wystarczająco dobre w pokoju, to jego zwiększanie nie jest czymś dobrym. Jeśli ktoś stwierdza, że jest w dobrym zdrowiu, to nie możemy mu życzyć lepszego zdrowia, bo właśnie dobre zdrowie jest dla niego najlepsze. Posługiwanie się stopniowaniem przymiotników jest więc zwodnicze, ponieważ dobro oznacza dla człowieka stan najwyższy. Lepsze może być wrogiem dobrego.

Konsekwencjonalistyczna maksymalizacja jako zasada definiowania dobra jest błędna w tym, że nie zauważa, że coś spełnionego nie musi i nie powinno być maksymalizowane. Jeśli ktoś np. po obiedzie zapytany, czy jest zadowolony, odpowiada, że jest syty i to mu wystarcza (enough), to maksymalizowanie i żądanie więcej jedzenia byłoby czymś niestosownym i szkodliwym. Niezrozumiała byłaby jego odpowiedź, że jest zadowolony, że obiad był wspaniały i dla niego w pełni wystarczający, ale chce go zmaksymalizować i prosi o więcej. Taka maksymalizacja miałaby cechy patologiczne $e^{34}$.

W argumentacji za dobrym i szczęśliwym życiem Savulescu używa dwóch terminów: well-being - dobrostan i worthwhile life - życie wartościowe. Okazuje się, że nie da się ustalić cech wartościowego życia na podstawie jakichś właściwości biologicznych czy psychicznych człowieka. Może być tak - stwierdza Holland - że pewne dysfunkcje genetyczne czy biologiczne, takie jak np. autyzm czy brak jednej ręki, mogą utrudniać dobrostan człowieka (jego well-being), ale nie są one przeszkodą uniemożliwiającą realizację wartościowego życia ${ }^{35}$.

W propozycjach wyselekcjonowania najlepszych dzieci podstawowe pojęcie wartościowego, najlepszego i szczęśliwego życia jest przez

\footnotetext{
33 A. Holland, The Case Against the Case for Procreative Beneficence (PB), dz. cyt., s. 496.

34 Zob. A. Holland, The Case Against the Case for Procreative Beneficence (PB), dz. cyt., s. 495.

35 Zob. A. Holland, The Case Against the Case for Procreative Beneficence (PB), dz. cyt., s. 492.
} 
wymienionych bioetyków normatywnie stosowane, ale kompletnie nieokreślone. Dla stoików np. dobre życie polegało na nabywaniu cnót $\mathrm{w}$ celu wzmocnienia się wobec przeciwności losu. Nie polegało ono na posiadaniu talentów ani na szczęśliwym zrządzeniu losu, a tym samym na genetycznym uposażeniu, „lecz całkowicie zależało od tego, co ty zrobiłeś z swoim własnym życiem"36.

Mimo że filozofia, w tym metafizyka i etyka Arystotelesa, od starożytności pochylała się nad pojęciem najwyższego dobra - celu życia, to jednak bioetycy libertyńsko-utylitarystyczni ignorują te osiągnięcia, tak jakby nie istniały żadne dotychczasowe ujęcia tej kwestii. Pojęcie dobrego życia jest pojęciem bogatym, gdyż dotyczy spełnienia się człowieka jako takiego, czyli spełnienia się jego człowieczeństwa. Spełnienie takie dokonuje się na poziomie moralnym czy religijnym. Spełnienie w sensie czasowo posiadanego dobrego zdrowia, czasowo posiadanego bogactwa nie jest spełnieniem człowieczeństwa jako takiego, lecz osiągnięciem pewnych dóbr potrzebnych czy koniecznych dla naszego rozwoju. Nie można spełnienia człowieczeństwa definiować w terminach cech biologicznych, bo wtedy zdrowie biologiczne przestępcy byłoby dobrem moralnym, a choroba człowieka sprawiedliwego byłaby złem moralnym. Mimo że wartości witalne są warunkiem realizacji wartości wyższych, to jednak nie one decydują o spełnionym człowieczeństwie.

Koncepcje, w których propaguje się selekcję istot ludzkich w okresie prenatalnym na rzecz tylko pomyślanych, lepszych biologicznie dzieci, prowadzą do dyskryminacji ze względu na wymyślone, wybiórcze cechy genetyczne czy biologiczne. Taka ideologiczna manipulacja życiem ludzkim nie jest prokreacyjnym dobrodziejstwem, lecz wprost przeciwnie jest eugenicznym niszczeniem życia ludzkiego i łamaniem prawa do życia. Niszczy ona należną dziecku akceptację wynikłą z osobowej miłości rodziców oraz jego przynależność i prawo wejścia do wspólnoty ludzkiej. Selekcja dehumanizuje relację rodziców do dziecka, które jest przyjęte tylko o tyle, o ile spełnia ich oczekiwania, tj. stanowi urzeczywistnienie ich wymyślonego projektu. 
Propagatorzy eugenicznego dobrodziejstwa prokreacyjnego stosują niebezpieczną manipulację etyczną, w której w imię tylko pomyślanego, nieistniejącego tzw. najlepszego dziecka nie tylko usprawiedliwiają, ale narzucają jako obowiązek moralny, likwidację, czyli zabójstwo dziecka istniejącego. Jest to nowa odsłona klasistycznej, zbrodniczej ideologii, w której ze względu na coś pomyślanego zachęca się do eliminacji realnie istniejących istot ludzkich. Ponieważ zawsze możemy pomyśleć ideę człowieka doskonalszego, więc odwołując się do takiej idei, czyli utopii, moglibyśmy usprawiedliwić każdą zbrodnię względem istniejących ludzi, argumentując to budowaniem lepszej ludzkości.

Takim rozumowaniem, wzmacnianym konsekwencjalistycznym rachunkiem maksymalizacji wyimaginowanego i nieokreślonego szczęścia ludzkości tłumaczy się eliminację tych, którzy stoją na drodze do jego realizacji. Można powiedzieć, że eugeniczne zbrodnie dokonywane w przeszłości w imię rasy aryjskiej teraz mają szerszą podstawę, bo mogą być podjęte w imię dobra i szczęścia nie tylko jednej rasy, ale całej ludzkości.

Obserwując wymienione wyżej dążenia teoretyków eugeniki, ruchów feministycznych, organizacji międzynarodowych i polskich, można przewidzieć, co się stanie, gdy zgodnie $\mathrm{z}$ wymienionymi ideologiami, zostanie zalegalizowane tzw. prawo do zdrowej reprodukcji. Termin "reprodukcja” ma swój źródłosłów w produkcji technicznej. To właśnie do takiej produkcji jest sprowadzana prokreacja. Chodzi w tym o oderwanie prokreacji od seksualności, od kobiecości i męskości, od macierzyństwa i ojcostwa. Chodzi w tym o oderwanie życia ludzkiego w okresie prenatalnym od międzyosobowej więzi kobiety i mężczyzny, od małżeństwa i rodziny, które traktowane są jako rzeczywistości opresyjne dla feministycznie rozumianej kobiecości. Reprodukcja taka to działalność techniczna, realizowana np. przez procedury in vitro, poprzez skup gamet rozrodczych i handel nimi czy handel zarodkami ludzkimi.

Jeśli się weźmie pod uwagę to, że tzw. prawa reprodukcyjne będzie można zastosować do jakości zarodków ludzkich, do jakości biologicznej człowieka w okresie prenatalnym, to prawo takie posiadaliby ci, którzy to dziecko zamówią i przyjmą. Jeśli ów „produkt” posiadałby jakieś 
nieakceptowane właściwości biologiczne, to zgodnie z tym prawem będzie można go zlikwidować. Prawo do zdrowia reprodukcyjnego kryje w sobie totalną eugenikę, którą będzie można realizować według biologicznych kryteriów jakościowych w procedurach in vitro, wraz z selekcją preimplantacyjną oraz selekcją aborcyjną rozwijających się dzieci w łonie matki. O możliwości urodzenia dziecka decydowano by zatem w oparciu o kryteria jakości towaru. Lekarze przy użyciu diagnostyki prenatalnej zmuszeni byliby śledzić dokładnie rozwój każdej ciąży i kierować na aborcję nawet $\mathrm{w}$ razie wątpliwości w kwestii zdrowia i różnych cech biologicznych rozwijającego się dziecka, gdyż na nich ciążyłaby odpowiedzialność za wrongful birth, czyli za złe urodzenie. W tym wypadku medycy sprowadzeni byliby do NKWD-zistów, których obowiązkiem byłaby dokładna obserwacja, śledzenie poprzez diagnostykę prenatalną kobiet oczekujących dziecka, by w razie odkrycia niechcianych cech biologicznych nasciturusa, wyeliminować jego urodzenie przez aborcję eugeniczną. Za niewykonanie tych zadań groziłyby lekarzom zarówno usunięcie z zawodu, jak i dotkliwe „odszkodowania” wraz z karą więzienia za dopuszczenie do urodzenia niechcianego dziecka. W wyniku zastosowania takiego prawa medycyna zostałaby użyta jako narzędzie zabijania tych nienarodzonych, których państwo i klasa urodzonych oskarżyła o brak wymaganych kwalifikacji.

\section{Bibliografia}

Bennett R., The Fallacy of the Principle of Procreative Beneficence, „Bioethics” 23 (2009) no. 5, s. 265-273.

Biesaga T., Spór o klauzulę sumienia lekarzy w Polsce, w: Primum philosophari. Opuscula Antonio Siemianowski dedicata, red. J. Grzeszczak, K. Stachewicz, Poznań 2016, s. 283-299.

Biesaga T., Źródła ideologii aborcyjnej, „Medycyna Praktyczna” 3 (2005), s. 26-33.

Binding K., Hoche A., Die Freigabe der Vernichtung Lebensunwerten Lebens, Leipzig 1920. Black E., Wojna przeciw słabym - eugenika i amerykańska kampania na rzecz stworzenia rasy panów, Warszawa 2004. 
Dobrowolska K., Prawa reprodukcyjne i seksualne w ONZ i ich doktrynalne uwarunkowania, „Zeszyty Prawnicze” 16 (2016) nr 2, s. 163-181.

Gawin M., Eugenika peryferii w pierwszej połowie XX w. w kontekście polskim, w: Eugenikabiopolityka - państwo: $z$ historii europejskich ruchów eugenicznych w pierwszej połowie XX w., red. M. Gawin, K. Uzarczyk, Warszawa 2010, s. 7-28.

Grant M., The Passing of the Great Race or Racial Basis of European History, Charles Scribner's Sons, New York 1916.

Holland A., The Case Against the Case for Procreative Beneficence (PB), „Bioethics” 30 (2016) no. 7, s. 490-499.

Komitet Bioetyczny przy Prezydium PAN, Stanowisko Komitetu Bioetycznego przy Prezydium PAN nr 1/2012 w sprawie etycznych problemów medycyny reprodukcyjnej i genetyki klinicznej oraz konieczności ich regulacji prawnej, http://www. bioetyka.pan.pl/images/stories/Pliki/stanowisko\%20kb\%20nr\%201-2012.pdf (6.10.2019).

Komitet Bioetyczny przy Prezydium PAN, Stanowisko Komitetu Bioetycznego przy Prezydium PAN nr 4/2013 z 12 listopada 2013 roku w sprawie tzw. klauzuli sumienia. http://www.bioetyka.pan.pl/images/stories/Pliki/Stanowisko\%20KB\%20nr\%20 4-2013.pdf (6.10.2019).

Madajczyk P., Rozliczenie z eugenikq i higiena rasowa po zakończeniu II wojny światowej, w: Medycyna w cieniu nazizmu, red. M. Musielak, K. B. Głodowska, Poznań 2015, s. $101-123$.

Programme of Action of the United Nations International Conference on Population \& Development, Cairo 1994. http:// www.iisd.ca/Cairo/program/p00000.html (6.10.2019).

Savulescu J., Kahane G., The Moral Obligation to Create Children with the Best Chance of the Best Life, „Bioethics” 23 (2009) no. 5, s. 274-290.

Savulescu J., Procreative Beneficence: Why We Should Select the Best Children, „Bioethics” 15 (2001) no. 5/6, s. 414-426.

Soniewicka M., Selekcja genetyczna w prokreacji medycznie wspomaganej. Etyczne i prawne kryteria, Warszawa 2018.

Turda M., Eugenika negatywna w Europie przed 1933 r., w: Eugenika - biopolityka - państwo: $z$ historii europejskich ruchów eugenicznych $w$ pierwszej połowie XX w., red. M. Gawin, K. Uzarczyk, Warszawa 2010, s. 29-48.

Weigel G., What Really Happened at Cairo, „First Things” 50 (1995), s. 24-31. 
Weindling P., Krytycy, komentatorzy i przeciwnicy eugeniki 1880-1950, w: Eugenika - biopolityka - państwo: $z$ historii europejskich ruchów eugenicznych $w$ pierwszej połowie $X X$ w., red. M. Gawin, K. Uzarczyk, Warszawa 2010, s. 49-62.

Żekanowski C., Genetyka medyczna: problemy i zagrożenia, w: Granice ingerencji w naturę, red. B. Chyrowicz, Lublin 2001, s. 87-128.

\section{Abstrakt}

\section{Eugenika w propozycjach legalizacji prawa do zdrowej reprodukcji}

Artykuł demaskuje prowadzone od wielu lat starania ruchów demograficznych, kontroli urodzeń i tzw. wyzwolenia kobiet dotyczące zalegalizowania prawa do tzw. zdrowej reprodukcji. Prawo to, przyznane rodzicom, zmuszałoby lekarzy do śledzenia poprzez diagnostykę prenatalną wszelkich schorzeń w okresie prenatalnym oraz do eugenicznej, aborcyjnej eliminacji instytucjonalnej dotkniętych tymi schorzeniami.

Tekst przywołuje również najnowsze projekty poszerzania prenatalnej selekcji eugenicznej. Są one propagowane przez bioetyków utylitarystycznych zalecających przeprowadzanie selekcji prenatalnej, manipulacji genetycznej czy aborcji w okresie prenatalnym $\mathrm{w}$ celu rodzenia jedynie zaprojektowanych najlepszych dzieci. Swoich zaleceń - rozpowszechnianych pod hasłem prokreatywnego dobrodziejstwa - nie tylko nie uważają oni za niemoralne, ale wprost przeciwne, propagują je jako moralny obowiązek rodziców. Rodzice ich zdaniem są moralnie zobowiązani do projektowania najlepszych dzieci, i w tym celu powinni mieć prawo do tzw. prokreatywnego dobrodziejstwa, czyli do eliminacji dzieci niespełniających ich oczekiwań.

\section{Słowa kluczowe}

Julian Savulescu, eugenika, selekcja eugeniczna, feminizm, prawa reprodukcyjne 


\section{Abstract \\ Eugenics in propositions of legalization of reproductive rights}

The paper reveals different efforts of population and birth control movements engaged for years in legalization so-called rights of reproductive health. This kinds of rights owned by parents would force physician by using prenatal diagnostic tests to check on unborn, ill children to eliminate them through institutional, eugenic abortion.

The article also presents recent projects to enlarge prenatal, eugenic selection. These are spread by utilitarian bioethicist who advised parents to do prenatal selection, genetic manipulation and abortion to produce best children. These recommendation for parents they treat not as immoral but as a Procreative Beneficence and moral obligation. According to them parents are morally obliged to project their best children and in the realization of Procreative Beneficence should have rights to eliminate those children who cannot fulfill their expectations.

\section{Keywords}

Julian Savulescu, eugenics, eugenic selection, feminism, reproductive rights 